\title{
The Role of Medical Honey (Medihoney) in Pediatric Medical Care: A Critical Review
}

\author{
Stefan Bittmann*, Elisabeth Luchter and Gloria Villalon \\ Department of Pediatrics, Ped Mind Institute, Germany
}

*Correspondence: Stefan Bittmann MD, MA, Department of Pediatrics, Ped Mind Institute, Hindenburgring-448599 Gronau, Germany, Tel: 0049-2565-97325; Fax: 0049-2565-97324; Email: stefanbittmann@gmx.de

\begin{abstract}
The use of complementary medical treatment in wound management has continued to grow throughout the world. There is a large body of evidence that supports the use of honey as a wound dressing for a wide range of types of wounds. We present an update of present knowledge using honey (Medihoney) as a form of complementary medicine in pediatric wound management.
\end{abstract}

Keywords: Honey; Medihoney; Pediatric; Complementary medicine; Child

Received Date: July 31, 2019; Accepted Date: August 23, 2019; Published Date: August 30, 2019

\section{Introduction}

The medical use of honey can be traced back a long time. The ancient Egyptians used honey for wound care. Evidence of the medical use of honey has been found in ancient scrolls, tablets and books. Sumerian clay tablets, estimated to date from 6200 BC, Egyptian papyri from 1900 to 1250 BC, Veda (Hindu script) about 5000 years old, the Holy Quran, the Talmud, both the Old and the New Testaments of the Bible, the holy books of India, China, Persia and Egypt all contain references to the early discovered medical value of honey [1]. In ancient Egypt the bee product was regarded as a remedy for wounds and was a successful remedy for intestinal complaints. However, the antibacterial properties of honey were first described in 1892 by Van Keetal [2].

\section{Composition of Honey}

As a food produced by honey bees, the exact chemical composition of honey varies depending on the herbalist and the season, with fructose and glucose always being the main components $[3,4]$. Three essential aspects of honey composition have been identified that contribute to its antibacterial activity: low water activity inhibits microbial growth, especially of bacteria. The low $\mathrm{pH}$, a result of the formation of gluconic acid, also has a mild antibacterial effect and can reduce the effect of proteases

Citation: Stefan Bittmann, The Role of Medical Honey (Medihoney) in Pediatric Medical Care: A Citical Review. J Clin Cases Rep 3(2): 59-65.

(C) 2020 Tridha Scholars 
http://www.tridhascholars.org | April-2020

[5]. Honey is slightly acidic with a pH of 3.9. Diluted with water, the enzyme glucose oxidase produces non-toxic amounts of hydrogen peroxide, which has an antibacterial effect [6,7]. Purified honey is defined by the purification of honey from the honeycomb of the bee, Apis mellifera and other Apis species. Potassium is the most important mineral. There are a number of other uncharacterized substances in some types of honey. Identified substances are syringic acid, 3,4,5-trimethoxybenzoic acid, 2-hydroxy-3-phenylpropionic acid and the flavonoid pinocembrin [8]. Many studies have shown that honey has an antibacterial effect due to its high osmolarity, low $\mathrm{pH}$ value, hydrogen peroxide content and other characteristic compounds $[3,4,9]$. In topical application to wounds, water is osmotically drawn from the wound so that the infected tissue dries and bacterial growth can be significantly reduced in this way.

\section{Studies on Antimicrobial and Antiviral Activity}

Honeys were categorized according to their floral source [10]. For most of the honey species tested, the destruction of the peroxide-generating ability by the use of catalase was associated with the loss of antibacterial activity. Manuka honey (Leptospermum scoparium) and viper's head (Echium vulgare) are excluded and maintain their antibacterial activity. In another study, complete inhibition of S. aureus growth was achieved at a Manuka honey concentration of $1.8 \%$ compared to $4.9 \%$ for other honeys. Despite the observed differences with different pathogens and honey varieties, the study showed that a number of honey varieties are most likely to achieve bacteriostatic effects at similar concentrations when applied topically to wounds. Sudanese honeys were investigated. The antibacterial effect of Sudanese honey was compared with that of five antibiotics: Ampicillin, cephadrine, chloramphenicol, gentamicin and oxytetracycline. The undiluted honey was directed against the pathogens B. subtilis, S. aureus, E. coli, Klebsiella and P. aeruginosa aerogenes. All the types of honey studied had an inhibitory effect against these bacteria, with gentamicin being the only antibiotic effective against $P$. aeruginosa. A recent study documented the sensitivity of multiresistant strains of Burkholderia cepacia to Manuka honey at concentrations below 6 percent. B. cepacia causes lung infections in cystic fibrosis. Recommended clinical applications for the treatment of B. cepacia with honey are honey-containing aerosols as an adjunct to antibiotic therapy and currently used for superficial infections and wounds. Honey's anti-inflammatory and antiviral properties have a direct anti-inflammatory effect on wounds, mainly due to significantly reduced bacterial growth [11]. Nitric oxide (NO) metabolites, nitrite and nitrate have been identified in different types of honey [12]. NO has antiviral activity against the DNA and RNA of various viruses [13]. There is some evidence of a direct or indirect blockade of HIV-1 replication by NO activity [13]. The enormous biological effects of honey can be explained by the presence of NO metabolites and the ability to upregulate their concentration [14,15] Various studies have found a benefit in the treatment of Herpes labialis with medicinal honey [16,17]. Animal studies have demonstrated the curative effect of medicinal honey. Many studies have shown the efficacy of honey in promoting the healing of standardized wounds in laboratory animals. These experiments have not only allowed for better comparability of other studies, but have also made histological examination of wound healing possible to obtain additional data in addition to the usual measurements such as wound area size and wound healing time. One study examined 24 male mice with skin excision of the neck region, $50 \%$ of which were treated with pure honey in a thin layer. The wounds were rubbed twice daily. During the control group "Saline" was applied with the same frequency and at the same time of day. Compared to the control group was in the mice treated with honey was a broader layer granulation tissue in the middle of the wounds [18]. In another study, deep skin burns had been investigated at twelve sites on the flanks of three pigs. The study compared the efficacy of honey, sugar solutions, both of which had very similar carbohydrate compositions and concentrations, and silver sulfadiazine on burnt tissue [19]. Honey and sugar showed faster healing than silver sulfadiazine, with wound healing within 21 days for honey and sugar versus 28-35 days for silver sulfadiazine. The mechanism by which honey produces a rapid and effective 
http://www.tridhascholars.org | April-2020

healing than sugar or silver sulfadiazine was not identified, although tissues treated with sugar had more myofibroblasts than the honey-treated tissues. Based on the theory of wound healing, honey causes fewer hypertrophic scars [20].

\section{Possible Safety Risks of Honey in Children}

Mad honey poisonings are allergies to honey, infant botulism and pain the most common complications after honey intake.

\section{Mad Honey Poisoning}

In cases of mad honey poisoning, bradycardia, cardiac arrhythmias such as bradycardia or AV block, cramps, vomiting, sweating, blurred vision, chills and cyanosis may occur [21,22]. Especially honeys from the Black Sea region contain grayanotoxin, which can be responsible for honey poisoning [22]. Various forms of grayanotoxin have been isolated from the leaves and flowers of rhododendrons and some other plants [22]. Animal studies have shown that grayanotoxin increases membrane permeability for sodium in sodium-dependently excitable membranes so that these cells enter a state of depolarisation $[19,23]$.

\section{Honey Allergy}

Honey allergy is not common but well known and can lead to anaphylaxis. Infant botulism is a rare disease caused by contamination of honey with Clostridia spores. It usually occurs in infants under 12 months, almost $95 \%$ of cases occur in the first 6 months of life.

\section{Infant Botulism}

No case of infant botulism has been described in the literature for topical use. Spores of Clostridia form colonies in the infant's intestine after oral ingestion, leading to constipation as the first sign of botulism. The concern about wound infection from Clostridium spores seems unfounded as no such complication has been described in more than 500 reports in the literature [24].

\section{Pain}

Some patients report pain in the application of medicinal honey. In these cases, there is a correlation between the concentration of honey and the severity of pain: higher concentrations of honey seem to cause a higher level of pain [25,26], which may be caused by the high osmotic potential (pulling pain) and/or a low pH value. However, pain does not seem to have a negative effect on healing rates, but it does affect patient compliance. In a comparative study of aciclovir and honey in the treatment of herpes labialis, a significantly lower duration of pain was found in the honey group [16]. These findings have been observed in the adult population, but have never been investigated in children.

\section{Discussion}

An ideal wound antiseptic meets the following four criteria: First, rapid onset of bactericidal action; second, improvement and acceleration of the physiological process of wound healing; third, no adverse local or systemic effects; and fourth, moderate costs. Normal wound healing is a highly regulated dynamic process in which the activity of several factors and cytokines are precisely coordinated. There is great interest in chronic wound healing products for products with antibacterial and antiinflammatory properties such as honey. Recent treatments with honey have shown that the antimicrobial properties promote 
http://www.tridhascholars.org | April-2020

autolytic debridement, stimulating tissue growth and the speed of wound healing. The anti-inflammatory activity relieves pain, edema and exudate production. Many comparative studies have been established and provided more data for generation of "medical device class" honey products [27-30]. Gamma-irradiated "medicinal honey" is available, which was also selected for its strong antibacterial properties, although in most cases medical literature has used raw honey [29-31]. Medihoney ${ }^{\mathrm{TM}}$ has been licensed as one of the first certified medical honeys as medical devices for professional wound care in Europe, the United States (FDA approval) and Australia [32,33]. Although the mechanism by which honey accelerates the healing process of wounds has not yet been identified, some results provide possible explanations: One approach states that honey, by stimulating an inflammatory response in leukocytes [34-36], triggers a cascade of cellular events leading to the production of growth factors and influencing angiogenesis and proliferation of fibroblasts and epithelial cells. Recently, Tonks discovered a 5.8 kDA component in Manuka honey that stimulates the production of TNF in macrophages via toll-like receptors [36]. Another mechanism focuses on the low $\mathrm{pH}$ of honey (3.4 to 5.5; mean 4.4) [37]. The healing conditions are often accompanied by $\mathrm{pH}$ values of about 7.3 in the wound exudates. However, this is also the $\mathrm{pH}$ range within which proteases have their optimal activity. Reducing the $\mathrm{pH}$ of the wound environment by using medicinal honey can reduce its activity and thus facilitate tissue regeneration. Many hypotheses have been made about the healing mechanism of honey. To date, none of these have been confirmed with certainty. However, obvious parameters such as the creation of a moist wound environment and a low $\mathrm{pH}$ value play a role in the antibacterial effect. Further intensive basic research is necessary. When evaluating clinical evidence, it is important to sort the available information according to the valid standards. For example, randomized controlled trials are mentioned as the highest level of clinical evidence. Case studies generally have a lower value [24, 29,30,38]. While these studies suggest that the tissue regeneration time was significantly shorter, the study quality was poor. The paper concludes that there is little evidence of the efficacy of honey therapy for superficial wounds or burns. This study showed that the available evidence from seven comparative studies with 264 patients was limited by lack of blinding, poor reporting and poor validity. Various authors demonstrate the need for a randomized controlled study on the medical use of honey [29,39-41]. Another study compared the efficacy of honey-soaked dressings, hydrocolloid dressings for the treatment of split skin sites after skin transplantation [42]. With regard to pain perception and wound healing speed, no significant difference between hydrocolloid dressings and honey-soaked dressings was found [42]. In this study, honey was compared with three controls, whereby the significantly faster tissue regeneration and the low pain scores were due to physical effects of honey and not to psychosomatic events [42]. In a 2007 Jull randomized controlled trial, honey-impregnated wound dressings showed no significant improvement in venous ulcer healing within 12 weeks compared to normal care [43]. However, it should be noted that statistical significance is rarely achieved in comparative tests of wound dressings. Many studies showed positive effects in the treatment of viral diseases and MRSA with honey [12,13,16,17,22,29,44,45]. These references mostly refer to case studies; statistical significance is missing. To date, there are few scientific results on the use of medicinal honey in the wound care of pediatric patients. Only a few case reports and a few controlled randomized trials exist for this clientele [29,30]. Scientific evidence for the use of conventional products in wound care is insufficient, especially for children and adolescents, as no prospective randomized studies have been carried out in this particular population group. Simon recently published that promising results have been achieved in the treatment of wounds in patients with pediatric hematology oncology [29]. He describes the treatment of a pediatric patient with acute myeloid leukemia (AML) and a wound infection with methicillinresistant coagulase-negative staphylococci using topical application of medicinal honey. The result was a successful healing without local or systemic complications. In a survey published in 2006, 15 pediatric-oncological patients with different diseases were successfully treated with Medihoney ${ }^{\mathrm{TM}}$ [29]. An Internet-based documentation system with standardized 
http://www.tridhascholars.org | April-2020

guidelines for the documentation of wound healing processes in children is introduced in a pediatric oncology center [45]. The main objective of this database is the cumulative analysis of prospectively documented treatment experiences from many participating centers, including children and adults. The microbiological and clinical studies mentioned demonstrate the benefits of medical honey as a wound care agent: bacterial growth can be controlled and contained, and health problems such as stomach ulcers, burns, leg ulcers and wounds in pediatric patients can be treated. Furthermore, medical honey stands out due to its antibacterial and antiviral effects and the lack of antibiotic resistance development as with conventional preparations and also because of its low purchase price. Both in the industrialized countries and in those below the poverty line, honey offers a cost-effective therapy for paediatric wound infections. Disadvantages of topical application of honey can occur in children with known but rare allergies to honey and the development of potential pain attacks. No case report from the literature on $C$. botulinum wound infection could be traced back to the application of irradiated honey.

\section{Conclusion}

First clinical studies were conducted in pediatric oncology patients. The use of medicinal honey in paediatric practices as primary wound care should be recommended. However, there are still no guidelines for the use of honey in paediatric wound care. Especially due to the limited experience with paediatric patients, extensive randomized controlled trials should be conducted in the near future to develop clear and consistent guidelines for paediatric wound care. The few studies already published on this topic show promising results. In summary, taking into account the studies mentioned above, it can be stated that the topical application of medical honey for wound care in children and adolescents offers enormous potential, but there are still unanswered questions regarding the treatment guidelines, so that further intensive research in this interesting field seems necessary.

\section{References}

1. Molan P, Betts JA (2004) Clinical usage of honey as a wound dressing: an update. Journal of Wound Care 13(9): 353-356.

2. Johnson DW, van Eps C, Mudge DW, et al. (2005) Randomized, controlled trial of topical exit-site application of honey (Medihoney) versus mupirocin for the prevention of catheter-associated infections in hemodialysis patients. Journal of the American Society of Nephrology 16(5): 1456-1462.

3. Jull A, Walker N, Parag V, et al. (2008) Randomized clinical trial of honey-impregnated dressings for venous leg ulcers. British Journal of Surgery 95(2): 175-182.

4. Narahashi T, Seyama I (1974) Mechanism of nerve membrane depolarization caused by Grayanotoxin I. The Journal of Physiology 242(2): 471-487.

5. Thomas S (1990) Wound Management and Dressings. London: Pharmaceutical Press.

6. Zumla A, Lulat A (1989) Honey - A remedy rediscovered. Journal of the Royal Society of Medicine 82(7): 384385.

7. Cooper R, Molan P, Krishnamoorthy L, et al. (2001) Manuka honey used to heal a recalcitrant surgical wound. European Journal of Clinical Microbiology \& Infectious Diseases 20(10): 758-759.

8. Natarajan S, Williamson D, Grey J, et al. (2001) Healing of an MRSA-colonized, hydroxyurea-induced leg ulcer with honey. Journal of Dermatological Treatment 12(1): 33-36.

9. Lawrence JC (1999) Honey and wound bacteria. Journal of Wound Care 8 (4): 155. 
http://www.tridhascholars.org | April-2020

10. Willix DJ, Molan PC, Harfoot CG (1992) A comparison of the sensitivity of wound-infecting species of bacteria to the antibacterial activity of manuka honey and other honey. Journal of Applied Bacteriology 73(5): 388-394.

11. Molan PC (2006) The evidence supporting the use of honey as a wound dressing. The International Journal of Lower Extremity Wounds 5(1): 40-54.

12. White Jr. JW, Riethof ML, Subers MH (1962) Composition of American honeys. Technical Bulletin No. 1261: $1-124$.

13. Bauer L, Kohlich A, Hirschwehr R, et al. (1996) Food allergy to honey: Pollen or bee products?: Characterization of allergenic proteins in honey by means of immunoblotting. Journal of Allergy and Clinical Immunology 97(1): 65-73.

14. Cooper RA, Molan PC, Harding KG (1999) Antibacterial activity of honey against strains of Staphylococcus aureus from infected wounds. Journal of the Royal Society of Medicine 92(6): 283-285.

15. Postmes TJ, Bosch MMC, Dutrieux R, et al. (1997) Speeding up the healing of burns with honey. An experimental study with histological assessment of wound biopsies. In: Mizrahi A, Lensky Y, editors. Bee Products: Properties, Applications and Apitherapy. New York: Plenum Press: 27-37.

16. Molan PC (1995) The antibacterial properties of honey. Chemistry in New Zealand 59(4): 10-14.

17. Slddiqui IR, Purgala B (1968) Isolation and characterization of oligosaccharides. Journal of Apicultural Research 7(1): 51-59.

18. Moore OA, Smith LA, Campbell F, et al. (2001) Systematic review of the use of honey as a wound dressing. BMC Complementary and Alternative Medicine 1(1): 2.

19. Al-Waili N (2003) Auswirkungen der aufnahme von honig auf stickoxid im speichel. FASEB Journal 17: A767.

20. Allen KL, Molan PC, Reid GM (1991) A survey of the antibacterial activity of some New Zealand honeys. Journal of Pharmacy and Pharmacology 43(12): 817-822.

21. Sofka K, Wiszniewsky G, Blaser G, et al. (2004) Antibakterieller honig (Medihoney TM) zur wundpflegewundantisepsis bei pädiatrischen patienten in der hämatologie-onkologie? Hospital Hygiene Infection Prevention 26 (5): 183-187.

22. Al-Waili NS (2004) Topical honey application vs. acyclovir for the treatment of recurrent herpes simplex lesions. Medical Science Monitor 10(8): MT94-MT98.

23. Bangroo AK, Khatri R, Chauhan S (2005) Honey dressing in pediatric burns. Journal of Indian Association of Pediatric Surgeons 10(3): 172-175.

24. Blaser G, Santos K, Bode U, et al. (2007) Effect of medical honey on wounds colonised or infected with MRSA. Journal of Wound Care 16(8): 325-328.

25. Al-Waili NS (2003) Identification of nitric oxide metabolites in various honeys: effects of intravenous honey on plasma and urinary nitric oxide metabolites concentrations. Journal of Medicinal Food 6(4): 359-364.

26. Molan PC (2001) Warum honig als medizin wirksam ist-die wissenschaftliche erklärung der wirkung. In Honig und Heilung. Munn P, Jones R (Eds.) Internationale Bienenforschung Verein.

27. Topham J (2002) Why do some cavity wounds treated with honey or sugar paste heal without scarring?. Journal of Wound Care 11 (2) 53-55.

28. Vardi A, Barzilay Z, Linder N, et al. (1998) Local application of honey for treatment of neonatal postoperative wound infection. Acta Paediatrica 87(4): 429-432. 
http://www.tridhascholars.org | April-2020

29. Dilber E, Kalyoncu M, Yaris N, et al. (2002) A case of mad honey poisoning presenting with convulsion: intoxication instead of alternative therapy. Turkish Journal of Medical Sciences 32(4): 361-362.

30. Gethin G (2004) Is there enough clinical evidence to use honey to manage wounds?. Journal of Wound Care 13(7): 275-278.

31. Dustmann JH (1979) Antibacterial effect of honey. Apiacta 14(1): 7-11.

32. Akinci S, Arslan U, Karakurt K, et al. (2008) An unusual presentation of mad honey poisoning: acute myocardial infarction. International Journal of Cardiology 129(2): e56-e58.

33. Tan ST, Wilkins AL, Molan PC, et al. (1989) A chemical approach to the determination of floral sources of New Zealand honeys. Journal of Apicultural Research 28(4): 212-222.

34. Lusby PE, Coombes AL, Wilkinson JM (2005) Bactericidal activity of different honeys against pathogenic bacteria. Archives of Medical Research 36(5): 464-467.

35. Cooper RA, Molan PC, Harding KG (2002) The sensitivity to honey of Gram-positive cocci of clinical significance isolated from wounds. Journal of Applied microbiology 93(5): 857-863.

36. Mphande ANG, Killowe C, Phalira S, et al. (2007) Effects of honey and sugar dressings on wound healing. Journal of Wound Care 16(7): 317-319.

37. Ambrose U, Middleton K, Seal D (1991) In vitro studies of water activity and bacterial growth inhibition of sucrose-polyethylene glycol 400-hydrogen peroxide and xylose-polyethylene glycol 400-hydrogen peroxide pastes used to treat infected wounds. Antimicrobial Agents and Chemotherapy 35(9): 1799-1803.

38. Dixon B (2003) Bacteria can't resist honey. The Lancet Infectious Diseases 3(2): 116.

39. Simon A, Sofka K, Wiszniewsky G, et al. (2006) Wound care with antibacterial honey (Medihoney) in pediatric hematology-oncology. Supportive Care in Cancer 14(1): 91-97.

40. White Jr. JW, Hoban N (1959) Composition of honey. IV. Identification of the disaccharides. Archives of Biochemistry and Biophysics 80(2): 386-392.

41. Misirlioglu A, Eroglu S, Karacaoglan N, et al. (2003) Use of honey as an adjunct in the healing of split-thickness skin graft donor site. Dermatologic Surgery 29(2): 168-172.

42. Lawrence JC (1999) Honey and wound bacteria. Journal of Wound Care 8(4): 155.

43. Molan PC (2001) Potential of honey in the treatment of wounds and burns. American Journal of Clinical Dermatology 2(1): 13-19.

44. Holzgreve H (2005) Honey is better than aciclovir in herpes. MMW - Fortschritte der Medizin 147(3): 18.

45. Cooper RA, Molan PC, Harding KG (1999) Antibacterial activity of honey against strains of Staphylococcus aureus from infected wounds. Journal of the Royal Society of Medicine 92(6): 283-285. 